\title{
Determinants, mechanisms and consequences of corporate governance reporting: a research framework
}

\author{
Charl de Villiers ${ }^{1,2} \mathbb{D} \cdot$ Ruth Dimes $^{1}$ \\ Published online: 3 September 2020 \\ (c) Springer Science+Business Media, LLC, part of Springer Nature 2020
}

\begin{abstract}
Corporate governance disclosures form a key part of a company's non-financial reporting. Several studies consider the determinants of corporate governance reporting, including external factors such as country-specific legislation and scandals, and internal factors such as financial performance, size and culture. Others consider the consequences of corporate governance reporting, using simple proxies for corporate governance mechanisms such as board composition characteristics to analyse the impact on financial reporting quality and company valuation. Yet the determinants and consequences of corporate governance reporting may be interlinked, and many quantitative studies fail to consider these links and their multiple effects adequately. Poor financial performance, for example, can be both a determinant and a consequence of the underlying governance mechanisms that corporate governance reporting aims to capture. The framework provided in this paper considers both the determinants and consequences of corporate governance and likely links between them, and also considers internal corporate governance mechanisms and the measures that are used as their proxies. In combining these three aspects of corporate governance and showing potential links, the framework offers insights into future research opportunities. The framework can be adapted to any country or organisational setting and also offers the opportunity to consider theories other than agency theory when studying corporate governance disclosures.
\end{abstract}

Keywords Corporate governance model - Corporate governance determinants · Corporate governance mechanisms $\cdot$ Corporate governance consequences

Charl de Villiers

charl.devilliers@auckland.ac.nz

Ruth Dimes

r.dimes@auckland.ac.nz

1 The University of Auckland, Auckland, New Zealand

2 University of Pretoria, Pretoria, South Africa 


\section{Introduction}

Corporate governance is the "exercise of ethical and effective leadership by the governing body towards the achievement of the following governance outcomes: ethical culture, good performance, effective control and legitimacy" (IODSA 2016), p20, and relates to the way that firms are governed rather than to the way they are managed. Reporting on corporate governance traditionally aimed to address and disclose relevant issues faced by boards of directors which were of interest to company stakeholders (Tricker 2015), although recently the range of interested stakeholders, and the concept of governance, has become much broader (Lai et al. 2019).

Corporate governance reporting can be considered part of the wider literature on corporate non-financial reporting, being subject to many of the same external and internal influences. However, there are also some specific features (such as corporate governance ranking scores) that are unique to corporate governance reporting that will be covered in this review. The aim of this paper is to provide a framework to consider for future research into corporate governance reporting, which is provided in Fig. 1. By providing an overview of the determinants, mechanisms and consequences of corporate governance reporting, and the many links between them, it suggests avenues for further research that are outlined in the concluding section.

There are many external and internal determinants of corporate governance disclosure. Country-specific legislation and cultural norms drive much of the disclosure (La Porta et al. 2000) but other external factors such as media interest and stakeholder activism also play a part (Uysal and Tsetsura 2015). Within organisations, financial performance (weak or strong) may result in a desire to provide more information regarding an organisation's corporate governance (Grove et al. 2011) as can pressure to conform to industry norms, demonstrate industry leadership to peers or mimic others (Tang et al. 2019). Firm-specific governance scandals are also very likely to result in changes to the nature of information provided by a firm

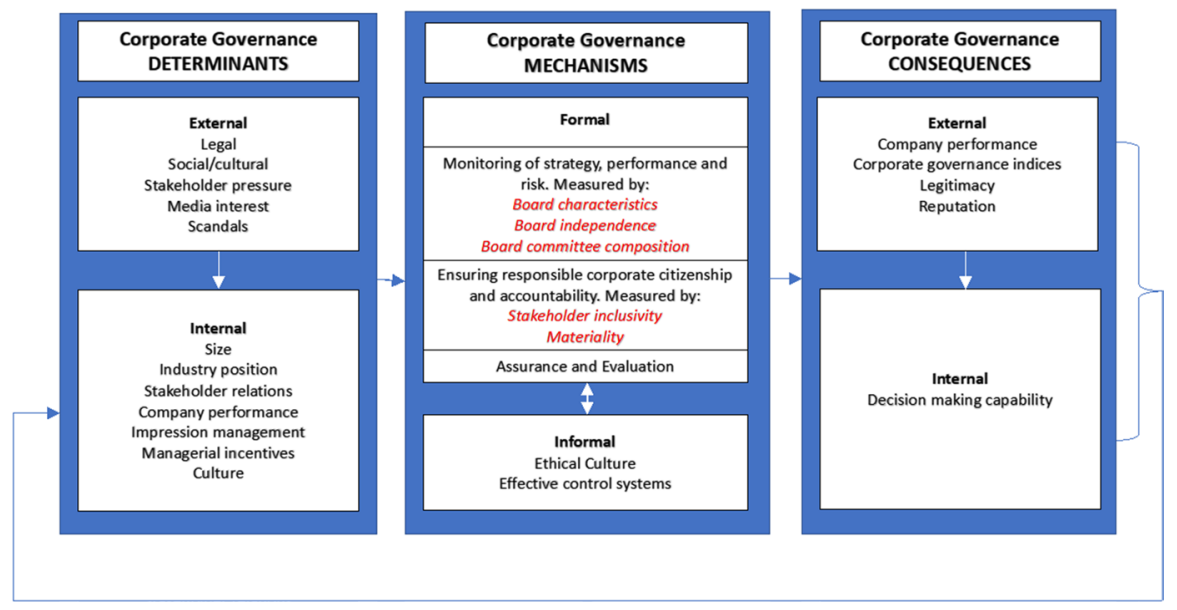

Fig. 1 Corporate governance reporting: a research framework 
(Christensen 2016). In addition, less observable factors such as organisational culture can be significant in terms of the level of transparency provided in corporate disclosures (Llopis et al. 2007).

The board and its committees not only provide a monitoring role, overseeing and advising on corporate strategy, performance and risk, but can also provide network links and resources to organisations (Endrikat et al. 2020). As corporate governance is so central to an organisation's successful operation, one of the key challenges when researching in this area is finding suitable metrics to use to measure the strength of corporate governance mechanisms (Bhagal et al. 2008). Corporate governance mechanisms such as board composition and meeting frequency are often used as proxies for underlying corporate governance quality, yet there are also informal mechanisms such as managerial attitude and organisational culture that, although less studied, are likely to be highly influential (Llopis et al. 2007).

Much of the research into corporate governance reporting centres on whether or not there are positive economic outcomes as a result of strong corporate governance practices (Grove et al. 2011). These are usually measured by Tobin's Q, improved cost of capital or changes in corporate governance ranking indices. These outcomes can also become subsequent determinants of corporate governance reporting, as indicated in Fig. 1. Yet there are also other less explored consequences such as improved corporate reputation and more effective decision making that can result from changes to corporate governance mechanisms (Lightle et al. 2009).

There are many complications with studies into corporate governance reporting. Many different input and output models are proposed, using different equations and measures, and coming to varying conclusions. In addition, it is likely that multiple factors will be influential with a concept as fundamental to organisations as corporate governance, even though many quantitative studies attempt to isolate particular characteristics in causal models (Endrikat et al. 2020). The dominance of quantitative research methods in this field also means that boards and their processes are often considered as a mysterious 'black box' (Parker 2017), and that mutual relationships, for example between accounting and governance, are not considered sufficiently in both contemporary and historical perspectives (Lai et al. 2019). To complicate it further, corporate governance characteristics and their effects are also often studied at different levels (individual, group, organisational and national) even though corporate governance itself is a broad multi-level construct (Dalton and Dalton 2011).

The majority of the literature that considers corporate governance reporting does so from an agency perspective, making the assumption that strong corporate governance reduces the opportunity for rent extraction by managers from shareholders (Jensen and Meckling 1976). Yet the increasing move towards providing non-financial information to a broader range of stakeholders (whether mandatory or voluntary) suggests that other theories, in particular stakeholder theory, may be worthy of further consideration in the corporate governance context (Stovall et al. 2004). In addition, according to resource dependency theory, effective boards should also not just monitor managers, but should also enable managerial entrepreneurship, bringing network benefits to stakeholders of the firm (Filatotchev 2007). Stewardship theory is also another lens through which to study corporate 
governance reporting, contrasting with agency theory in making the assumption that company directors can be trusted to act in the public good (Calder 2008).

The contribution of this study is the proposal of a simple framework to guide corporate governance research. The aim of the framework is to capture the major influences on corporate governance, and to acknowledge the multitude of potential links between them (Endrikat et al. 2020), supporting the calls for more multidimensional research into corporate governance (Dalton and Dalton 2011). The framework in Fig. 1 provides an overview of the key determinants, internal mechanisms (and corresponding measures) and consequences of corporate governance, and the links between them. Similar frameworks have been proposed to consider the determinants of other types of non-financial disclosure, such as sustainability disclosures (Alrazi et al. 2015). The Alrazi et al. framework indicates how both internal and external determinants play a part in internal sustainability mechanisms, and eventually organisational accountability, and bears many similarities to the left hand side of the framework shown in Fig. 1. However, the Alrazi et al. framework does not consider the consequences of reporting, and the links between consequences and determinants which Fig. 1 does.

The framework above shows the major determinants, mechanisms and consequences of what can determine either strong or weak corporate governance. Determinants and consequences can be both external and internal, and there are also multiple links between them. For example, company performance (financial or non-financial) is both a consequence and possible determinant of corporate governance strength. Section 2 explores the determinants, Sect. 3 the internal mechanisms, and Sect. 4 the consequences of corporate governance, and Sect. 5 discusses the potential links between them. Section 6 considers the opportunity for exploring corporate governance through other theories, such as resource dependency, stakeholder and stewardship theory. Section 7 concludes and suggests avenues for future research.

\section{Determinants of corporate governance reporting}

Figure 1 indicates that the determinants of corporate governance reporting can be both external and internal, and for most organisations are likely to result from a combination of external and internal factors. Many studies examine causal connections between external factors such as country-specific legal guidance and internal factors such as reactions to company-specific pressures on a company's likelihood to disclose information about their corporate governance (Cahan et al. 2016). Like other types of non-financial disclosure, these disclosures may be superficial (just providing legally required information) or may reflect deeper underlying changes to corporate governance mechanisms and internal control quality (Wang 2010). However, corporate governance studies have been criticised for their use and measurement of multiple country-level factors to explain country and firm specific governance mechanisms, making comparisons difficult (Schiehll and Martins 2016), and for their focus on an economic rather than an institutional perspective. 


\subsection{External determinants of corporate governance reporting}

\subsubsection{Legal}

Companies may report corporate governance information because it is mandatory, or offer disclosures information voluntarily. It is important to distinguish between these two types of information provision, as voluntary reporting introduces a number of other potential influences, as for the voluntary reporting of any other type of non-financial information.

Mandatory corporate governance reporting Most countries have their own corporate governance codes which influence corporate governance mechanisms and their disclosure. The level of an organisation's internationalisation may also mean that it needs to comply with corporate governance codes in multiple jurisdictions. There are two main approaches to governance regulations - a highly prescriptive 'apply or die' approach such the Sarbanes-Oxley Act (SOX) 2002, which involves significant financial and criminal penalties for non-compliance, and a more selfregulated principles-based 'apply or explain' approach based on the Cadbury Code of 1992 which was subsequently developed into the UK Combined Code (Calder 2008). A further development of the principles-based approach is the 'apply and explain' (apply principles and explain practice) approach which is a hallmark of the King IV governance code in South Africa, which promotes an outcomes-based view of governance based on Integrated Reporting (IODSA 2016). SOX is probably the most significant piece of legislation around corporate governance ever introduced, following a wave of major corporate governance scandals, most notably the Enron case. SOX sets out a series of requirements which has resulted in stock exchanges increasing their requirements for the independence of directors and establishment of committees headed by non-executive directors (Bebchuk et al. 2009). The mandatory disclosures required by SOX, for example around internal controls, are aimed at reducing information asymmetry, driven by the need to control the excessive managerial discretion seen in the Enron case. Self-regulated corporate governance codes such as the UK and South African examples above can lead to different interpretations of corporate governance within firms (Okhmatovskiy and David 2012), showing that the governance context within which firms operate is a critical determinant to consider.

Voluntary reporting - legal and social Although SOX and other regulations relate specifically to corporate governance activities and disclosures, other types of mandatory disclosure and reporting can also influence corporate governance reporting. For example, the recent EU Directive on non-financial reporting, even though it allows considerable flexibility, is likely to result in firms providing additional corporate governance disclosures (Camilleri 2015). Increasing interest in CSR disclosures has also led to improvements in the disclosure of relevant corporate governance information (Kolk and Pinkse 2010). As corporate governance is so central to a company's operations, mandatory disclosures of other types may well result in the provision of additional corporate governance information to shareholders, either explicitly or implicitly. Country-specific governance factors such as legal origin, investor protection regulations and culture may affect how organisations choose to present their 
corporate governance information (La Porta et al. 2000). Increased public scrutiny and regulatory oversight can also result to changes in the type of corporate nonfinancial information provided (De Villiers and van Staden 2011). Many stakeholders, not just financial ones, have an interest in the corporate governance information provided by a firm, and many corporate governance codes (including South Africa's King codes and the UK's Combined Code) consider management to have a duty of responsibility to a broad stakeholder base, operating under a social licence which requires them to consider stakeholder needs and prevailing social norms (Suchman 1995). The social and cultural norms in different countries can also influence corporate governance, with research showing that countries with a higher preference for rules tend to have better corporate governance (Duong et al. 2016).

\subsubsection{Stakeholder pressure, media interest and scandals}

Other external pressures include stakeholder pressure (Alrazi et al. 2015) which can be exacerbated by direct or indirect media pressure (Shipilov et al. 2019). The emergence of multi-stakeholder NGOs, and broad initiatives such as the GRI and UN SDGs are increasingly influencing organisational norms (Grosser 2016). Corporate scandals for other firms can also trigger a renewed interest in corporate governance in certain sectors or countries. The Enron scandal, for example, renewed interest in corporate governance disclosures for all organisations, regardless of their sector (Calder 2008). Scandals specific to a certain industry may also lead to increased regulatory and media scrutiny for all organisations in the industry, regardless of their own track record in corporate governance (Bebchuk et al. 2009).

\subsection{Internal determinants of corporate governance reporting}

\subsubsection{Size and industry position}

A company's size, industry position and global scale may influence its likelihood to report corporate governance information voluntarily. Firms providing more CSR information have been found to be large, in high profile industries and more highly leveraged, and also to possess better corporate governance ratings (Chan et al. 2014). High quality disclosures may help larger, more successful organisations to differentiate themselves from their competitors (Eccles and Krzus 2010). Smaller firms, especially family owned ones, have less incentive to provide information around their corporate governance voluntarily (Satta et al. 2014).

\subsubsection{Stakeholder relations and company performance}

Pressure may also come from the ownership of the organisation, particularly when there are institutional or block shareholders who may influence firm performance (Bushee 1998) and disclosures (Bae et al. 2012). Depending on the size of the firm, director shareholdings may also be an influencing factor (Satta et al. 2014). In addition to shareholder pressure, there may be pressure from other non-owner activists to 
include particular types of information, for example board diversity statistics (Uysal and Tsetsura 2015).

The financial performance of an organisation may also be a contributing factor to corporate governance disclosures. Weak financial performance may result in closer scrutiny of corporate governance practices, and managerial compensation structures for example (Grove et al. 2011). An organisation's level of leverage is also likely to be a contributing factor, as when bank debt levels increase, external monitoring by banks may become exert more significant influence (Jensen 1986). Company-specific scandals are also likely to lead to changes in disclosures of ESG information (Utz 2019).

\subsubsection{Impression management, managerial incentives and organisational culture}

Companies often look to their peers when preparing annual report disclosures, resulting in the potential for mimicry, particularly for organisations newer to a particular type of reporting, or smaller organisations attempting to save time and expense by following the disclosures of their larger peers (Tang et al. 2019). There may also be peer pressure within the board itself (possibly from NEDs with other board positions) and CEO peer pressure to disclose certain types of corporate information. Agency theory would suggest that managers are only likely to provide such additional disclosures if they paint them in a good light (Beattie 2014), and impression management has been shown to contribute to other non-financial disclosures such as business model disclosures (Melloni et al. 2016).

There are other more informal reasons for the voluntary disclosure of corporate governance information. Corporate governance is closely related to company culture, which in turn is closely connected to managerial attitudes. A change in corporate culture towards a more transparent and collaborative culture may result in the voluntary provision of additional information externally (Llopis et al. 2007). Other researchers have suggested that looking at corporate governance from a behavioural science perspective would be useful, particularly as key managers (the CEO) and board members exert considerable influence over corporate governance practices and organisational culture (Hambrick et al. 2008).

\section{Corporate governance mechanisms}

A board's role is to help to set and steer an organisation's strategic direction, monitor planning and policies and ensure accountability. The outcomes of good corporate governance are therefore not only good financial performance, but also the development of an ethical culture, effective control systems and ultimately organisational legitimacy (IODSA 2016). A large body of research considers corporate governance characteristics and their influence on effective corporate governance outcomes. Much of this quantitative research assumes that corporate governance characteristics, for example board and committee composition and board meeting frequency, capture the quality of the underlying corporate governance mechanisms. However, many of the studies consider formal mechanisms alone, and do not consider informal 
mechanisms such as organisational culture, which may be highly influential, particularly in smaller firms (Satta et al. 2014).

\subsection{Formal corporate governance mechanisms}

Corporate governance mechanisms within a firm (as distinct from those mechanisms imposed externally by a country's legal framework) comprise the set of rules, processes and processes that either formally or informally enable the board of directors to govern. These enable the monitoring of strategy, performance and risk and encourage good corporate citizenship and organisational accountability. There are several proxies used as measurements of formal corporate governance mechanisms, the most common of which are board size and composition, committee size and composition, board independence, and factors such as meeting frequency. The existence of formal procedures and policies, for example whistle-blowing policies, and external assurance, are also examples of formal governance mechanisms.

\subsubsection{Monitoring of strategy, performance and risk}

One of a board's primary roles is the monitoring of management (Endrikat et al. 2020). In order to be able to monitor effectively, a board needs to have the appropriate capabilities, including experience and a broad perspective. In addition, a board should be independent of a firm's management in order to be able to oversee activities effectively. Formal procedures such as board evaluation and assurance can help to give confidence in a board's ability and independence. Consistent with agency theory, a capable and independent board subject to review and assurance should minimize rent extraction by management (Jensen and Meckling 1976).

Board characteristics The size of a board (number of board members) can signal managerial ability and expertise, which should improve the quality of information disclosure, and several studies support this view (Cooray and Senaratne 2020; Jizi et al. 2014). Board size is also positively related to CSR (Endrikat et al. 2020). Not only does board size suggest a breadth of experience in order to monitor management, it also means that firms can potentially benefit from the connections of board members (Endrikat et al. 2020). Diversity (of gender, race, and experience) is also studied extensively, with studies investigating the impact of different characteristics of the board on firm performance. Gender diversity (usually measured as the proportion of women on boards) is argued to have a positive impact on the quality of voluntary disclosures including environmental disclosures (Cooray and Senaratne 2020; De Villiers 1998) and it is possible that gender diversity also contributes to the quality of corporate governance disclosures. Certainly research has found women to have a different attitude towards risk than men (Croson and Gneezy 2009). However, other studies have found negative associations between both gender and age and firm performance (Shehata et al. 2017), and suggest that other factors such as firm size may be influential in the relative importance of board diversity.

Another aspect of corporate governance that is commonly disclosed is board meeting frequency and attendance. Board meeting frequency has been found to have 
no significant association with financial performance (Grove et al. 2011), although others have found that insider ownership reduces board and committee meeting frequency, whereas NEDs increase it, suggesting that board independence may be a contributory factor (Greco 2011).

Board independence Board independence is also associated with improved corporate disclosure quality (Xia and De Beelde 2018) and financial performance (Chou et al. 2013). Board independence can be measured by the number of nonexecutive directors (NEDs), as the assumption is that they will be able to reduce executive director dominance over decision-making (Forker 1992). However, this formal measure may miss the informal network connections between directors and the CEO outside the boardroom which could compromise director independence (Fracassi and Tate 2012). Also, from a resource-dependency perspective, the independence of board members suggests more external contacts and connections which could benefit the firm (Hillman and Dalziel 2003). The absence of CEO duality (the CEO and board chair roles being held by the same individual) is also a measure of board independence, although findings as to its effectiveness are mixed (Grove et al. 2011). In both independence measures the assumption from an agency theory perspective is these mechanisms mean that executive directors will not be able to dominate decision-making, which should improve the information flow to stakeholders (De Villiers et al. 2011; Forker 1992). However, research supporting these basic assumptions of agency theory are inconclusive, involving multiple differing measures of both board independence and financial performance (Dalton and Dalton 2011).

Board committee composition Board committees are a delegation mechanism for boards, allowing for the effective discharge of a board's duties by the use of smaller, independent, focused decision-making bodies (IODSA 2016). The number of committees can mitigate the potential inefficiencies that may result from very large boards (Upadhyay et al. 2014). The main committees that are commonly studied in this light are audit committees, risk committees, nomination and remuneration committees and various types of ESG/CSR committee. The existence of such committees, along with their composition (using similar composition metrics as for boards), are variables of interest in several studies looking at financial and non-financial outcomes, and can potentially give insights into how boards discharge their monitoring duties.

Audit committees, a statutory necessity in some jurisdictions, play an active role in improving corporate disclosures through their focus on internal controls and high quality reporting processes. The relative independence of an audit committee (achieved through a higher proportion of independent members) should also improve disclosure quality (Forker 1992). Other studies consider a separate risk management committee as an important feature, particularly for the provision of high quality risk-related information disclosures (Tao and Hutchinson 2013). Nomination and remuneration committees, with their role in CEO appointment and remuneration in particular, are the subject of focus for academic studies as they can help to indicate the relative independence of management (Kaczmarek et al. 2012). Evidence shows that the composition characteristics of ESG and CSR committees can improve social responsibility outcomes (Eberhardt-Toth 2017). The existence of 
committees, however, does not necessarily mean that they function effectively (Carrott 2013) and committees may also play a mediating rather than a direct role in terms of corporate disclosures (Endrikat et al. 2020), again indicating the importance of not considering causal effects in isolation.

\subsubsection{Ensuring responsible corporate citizenship and accountability}

Despite the agency focus of much research into corporate governance, there is increased recognition of the importance of CSR and ESG related matters to firms. The board of directors have a responsibility to a broader set of stakeholders than just shareholders and increasingly need to consider society at large to ensure organizational legitimacy (Suchman 1995).

Stakeholder inclusivity The emergence of multi-stakeholder global governance initiatives such as the UN SDGs and GRI influence the policies and practices of firms, suggesting that more academic attention should be paid to stakeholders other than shareholders. The existence and composition of ESG and CSR committees, as mentioned earlier, is considered as a proxy for shareholder inclusivity in some studies, but these do not really consider a firm's multiple stakeholders, particularly marginalised ones (Grosser 2016). Board composition may be indicative of stakeholder inclusivity, but is unlikely to reflect how decisions are prioritised internally.

Materiality With the proliferation of data available to directors, and the increasing scope of the firm in society, there needs to be an effective way of prioritizing decisions. Although often associated with corporate reporting, materiality is as much a governance issue as a reporting one (Eccles and Youmans 2016). The ultimate responsibility for materiality rests with the board of directors, who need to determine which stakeholders and which particular issues are of the most importance to a firm. Integrated Reports often include a statement around materiality, and some studies have found a link between board diversity statistics and the quality of materiality disclosures (Fasan and Mio 2017). Content analysis of such disclosures may yield insights into decision making mechanisms within firms that are not as evident in simple board or committee composition statistics.

\subsubsection{Assurance and evaluation}

Assurance is a potential mechanism to improve governance, as companies traditionally use external assurance to reduce risks and review the effectiveness of governance practices, implying a managerial commitment to transparency and reliability (Simnett and Huggins 2015). However, studies come to mixed conclusions as to the effectiveness of assurance, as without corresponding changes to underlying mechanisms, it can be seen as just a public-relations exercise (Segui-Mas et al. 2018). Whistle-blowing regulations and policies are another corporate governance mechanism, although research has shown mixed results on their effectiveness, noting that results are highly dependent on the underlying corporate governance practices both within firms and also within different countries (Pittroff 2016). Independent evaluation or self-evaluation of the board's effectiveness are also assurance mechanisms 
which are encouraged by many governance codes, including the UK's Combined Code (Long 2006).

\subsection{Informal corporate governance mechanisms}

\subsubsection{Ethical culture}

The tone at the top of an organisation is likely to determine how corporate governance practices are institutionalised. Studies have found that when employees perceive management as trustworthy and ethical, the performance of the firm is stronger, indicating that traditional measures of corporate governance may have less of an impact than originally thought (Guiso et al. 2015). Indeed, many corporate governance scandals are centred on stories of unethical leadership (Boddy 2013). However, despite the importance of corporate culture to the effectiveness of corporate governance mechanisms, it is difficult to measure through corporate governance reporting, although potential measures could include a reduction in corporate scandals, or improvement in corporate reputation rankings.

\subsubsection{Effective control systems}

Corporate culture can be considered as part of the wider scope of both formal and informal management control systems. However, the different management control mechanisms used for a concept as broad as corporate governance are difficult to isolate for the purpose of causal studies, as many are likely to be interrelated (Endrikat et al. 2020). Evidence has shown, however, that not only are management control systems used to embed corporate governance practices, they can also change them (Ferry and Ahrens 2017). Control systems are usually studied qualitatively, yet qualitative studies constitute a tiny proportion (less than 1\%) of studies into corporate governance, and there have been calls for more research of this type to yield deeper insights (Mcnulty Zattoni and Douglas 2013). The dominance of quantitative research methods, rather than qualitative or mixed methods, has led to corporate governance processes themselves being bypassed in academic research and poorly understood as a result (Parker 2017).

\section{Consequences of corporate governance reporting}

The main consequences of corporate governance reporting that are considered by academic studies are improved firm value (usually measured by Tobin's Q) and reduced cost of capital. In addition, the existence of corporate governance rankings acts as a mediating factor, with these rankings both a consequence of and a determinant of future financial performance. Other consequences of corporate governance reporting include corporate reputation, legitimacy and the potential for scandals and fines. There may also be internal consequences of corporate governance reporting, such as changes to managerial incentive structures and improved decision making. 


\subsection{External consequences of corporate governance reporting}

\subsubsection{Company performance}

Consistent with agency theory, firms with stronger governance are associated with better financial performance (Grove et al. 2011). As a consequence of the disclosures required by SOX, CFOs at organisations with stronger internal controls received higher executive compensation, and were less likely to depart their roles than CFOs at firms with weaker controls (Wang 2010). Firms with perceived weaker governance are associated with higher CEO pay, and an increased propensity to use compensation consultants (Armstrong et al. 2012). Entrenchment provisions such as staggered boards and supermajority voting requirements for takeovers have been found to reduce firm value, as measured by Tobin's Q (Bebchuk et al. 2009). The transparency of financial and non-financial information should therefore be associated with value creation opportunities (Cooray and Senaratne 2020). However, other theories can also explain the links between board characteristics and corporate governance outcomes. As boards also provide access to networks and resources, certain board characteristics resource provision determine the association between board characteristics and firm performance, following resource dependency theory (Hillman and Dalziel 2003).

There have also been studies into non-financial consequences of reporting, such as environmental performance (De Villiers et al. 2011), and links have been suggested between high corporate governance quality and improved CSR disclosures (Chan et al. 2014), although as CSR is a multi-dimensional construct many of these studies use different measurements for CSR (Wang et al. 2016). The many similarities between CSR and corporate governance reporting also make it difficult to isolate the effects of the corporate governance reporting alone.

\subsubsection{Corporate governance indices}

Corporate governance rankings are widely used, and are therefore likely to contribute to how organisations report their corporate governance. There is inconsistent evidence of an association between corporate governance rankings and financial performance, possibly because of the difficulties associated with constructing meaningful measures, and the multitude of different commercial and academic corporate governance indices available (Chan et al. 2014). These rankings and indices can be both a determinant and a consequence of corporate governance, and may add to the pressure on corporations to adapt their governance reporting and mechanisms, even to fit a benchmark that may be unsuitable to their unique circumstances (Lysandrou and Parker 2012). An additional consequence of corporate governance rankings comes from their relative importance to institutional investors, with some arguing that rankings are not used to predict financial performance, but instead are used to capture reduced risk, useful in the construction of trading portfolios (Lysandrou and Parker 2012). CSR ratings are also closely related to corporate governance rankings, and can mediate the effect of corporate governance characteristics on reputation (Bear et al. 2010). 


\subsubsection{Legitimacy and reputation}

Legitimacy is a critical outcome of corporate governance reporting, as companies operate under social licences which expect them to conform to certain values and beliefs (Suchman 1995). A failure of legitimacy can lead to dissatisfied stakeholders withdrawing capital and business, or voicing their concerns through regulators or the media (Alrazi et al. 2015). Some studies have found links between certain corporate governance characteristics, such as gender diversity, and improved firm reputation (Bear et al. 2010). However, there may be other mediating influences on firm reputation, such as the legal environment and shareholder and creditor rights (Soleimani et al. 2014).

\subsection{Internal consequences of corporate governance reporting}

\subsubsection{Decision making capability}

Reporting on corporate governance should improve corporate accountability and operational management, making companies less likely to engage in high-profile misconduct, and less likely to incur financial punishment in terms of stock price reaction if they do (Christensen 2016). Certain board and committee characteristics, such as the level of financial expertise, have been found to correlate with internal control quality (Hoitash et al. 2009). Generally, it is assumed that boards have significant influence in terms of helping to shape an organisational culture that promotes good corporate governance (Lightle et al. 2009). However, it is certainly possible to change external reporting of any type without the underlying decision making processes changing (Stubbs and Higgins 2014) if the provision of such additional information is just regarded as a compliance exercise.

\section{Links between determinants, mechanisms and consequences}

The framework in Fig. 1 indicates the multiple links between determinants, mechanisms and consequences of corporate governance. The existence of these multiple links, in particular the links between consequences and determinants, are important to consider in any causal model, as many of them point to the potential for reverse causality, along with the multiple measurement and correlation issues already discussed. Corporate governance mechanisms may also act as complements or substitutes for one another, depending on the governance context (Satta et al. 2014). This framework indicates that although many academic studies into corporate governance use causal models based on agency assumptions, these models are likely to be overly simplistic given the multiple potential influences at both a macro and micro level. Calls for more research using other methodologies and considering different theoretical perspectives appear valid considering this 
review (Mcnulty et al. 2013), and the framework proposed in Fig. 1 allows for these different perspectives.

\section{Theories of corporate governance reporting}

A key concept of corporate governance is accountability, and corporate governance mechanisms can be used to extend managerial accountability beyond just shareholders to a wider set of stakeholders (Cooray and Senaratne 2020). There have been increasing calls to consider corporate governance from a broader perspective than the shareholder primacy perspective that still dominates the literature (Cheung 2018; Endrikat et al. 2020; Grove et al. 2011). The Anglo-American focus on agency theory in the majority of academic research also ignores the fact that in some economies, such as China, the state has control over listed companies, resulting in very different pressures on firms (Habib and Jiang 2015). Agency theory assumes that directors are self-serving, needing to be monitored and controlled to ensure that shareholder interests are met (Jensen and Meckling 1976). Studies with an agency theory perspective assume that corporate governance mechanisms exist to reduce information asymmetry, thereby minimising the rent extraction by managers from shareholders and maximising the value of the firm (Jensen and Meckling 1976). Agency theory therefore proposes that firms with stronger governance are associated with better financial performance (Grove et al. 2011) and firms with perceived weaker governance are associated with increased rent extraction such as higher CEO pay (Armstrong et al. 2012).

However, other theories can also explain the links between board characteristics and corporate governance outcomes. Stakeholder theory considers managers to be accountable to a much broader set of stakeholders than just shareholders, and posits that information provided by firms should not only reduce information asymmetry (Jensen 2010), but also reduce conflicts of interest between different stakeholder groups (Velte and Gerwanski 2020). Stewardship theory also considers a broader range of stakeholders than the shareholder primacy model, and with the increase in non-financial and integrated disclosures may need to be considered further as a basis for any type of corporate governance disclosures (Dumay et al. 2019). Proponents of stewardship theory are resistant to the regulation of corporate governance, for example restrictions on CEO duality, as the theory holds that directors can generally be trusted to act in the public good (Calder 2008). Along with their role as a monitor of managers, boards can also provide access to networks and resources, suggesting that resource dependency theory is also a useful angle to consider (Endrikat et al. 2020; Hillman and Dalziel 2003). There is also the market theory of corporate governance, which ignores the relative perceptions of managers as stewards or agents and assumes instead that poor investment returns will be punished by shareholders selling their shares. This theory, however, has been undermined by scandals such as Enron where employees were unable to sell their shares even when they were made aware of existing corporate governance weaknesses (Calder 2008).

The Framework in Fig. 1 offers the potential to consider theories other than agency theory when considering corporate governance determinants, mechanisms 
and consequences, responding to more calls for research of this type (Parker 2017; Habib and Jiang 2015; Mcnulty et al. 2013).

\section{Conclusion and research avenues}

\subsection{Conclusion}

Strong corporate governance is associated with improved firm performance and organisational reputation and legitimacy (Bear et al. 2010; Grove et al. 2011). The framework provided in this article recognises that the determinants, mechanisms and consequences of strong or weak corporate governance are often linked, and that many contributing external and internal factors can be studied. This article is not intended to be a comprehensive review of the literature, neither is the framework designed to be exhaustive. Instead, it aims to place the key interlinked factors into a simple model for reflection and for the generation of new research ideas and methods. The framework helps to highlight gaps in existing literature, notably in the area of governance mechanisms. Although there are many different measures that are used as proxies for underlying governance mechanisms, there is little research on the effectiveness of these mechanisms in practice (Parker 2017). Potential avenues for future research in this and other areas are highlighted below.

\subsection{Avenues for further research}

Although reporting on corporate governance aims to convey the underlying strength of corporate governance mechanisms, in reality corporate governance, embedded as it is throughout organisations, is difficult to measure. Metrics taken from reporting on corporate governance, such as board composition statistics, are widely used yet may not reflect underlying corporate governance capability, which can be influenced by less formal mechanisms such as organisational culture (Hambrick et al. 2008). As such, qualitative studies into corporate governance, in particular research into management control systems could help in challenging some of the dominant assumptions in the existing corporate governance literature about how actors and organisations actually operate (Mcnulty et al. 2013; Parker 2017). Looking at corporate governance from a behavioural science perspective would also potentially be useful, particularly as key managers (the CEO) and board members exert considerable power over corporate governance practices and organisational culture (Hambrick et al. 2008) and the majority of existing research is focussed on whole boards rather than individual actors (Mcnulty et al. 2013). Board and managerial attitudes towards corporate governance may also be captured by narrative disclosures rather than quantitative disclosures in annual reports and other data (for example website data) captured by the firm (Short et al. 2010), suggesting that content analysis might be a useful methodology to employ.

Much of corporate governance research focuses on particular reported statistics such as board composition, or board meeting frequency and economic outcomes 
such as improved financial performance or changes to CEO compensation structures. Yet as with other types of managerial research, corporate governance operates at an individual, group and firm level. Studying firm-level outcomes that relate to individual-specific matters such as CEO duality may be misleading, and it would be useful to consider the multi-level nature of corporate governance when researching into how it is reported (Dalton and Dalton 2011). In addition, much of corporate governance research is conducted at an economic rather than an institutional level (Schiehll and Martins 2016), and even if it is conducted at a firm level it focuses predominantly on large firms, which have clearer agency structures and different governance issues compared to SMEs (Satta et al. 2014).

Traditionally, research into corporate governance takes an agency view of the firm, following (Jensen and Meckling 1976), although recent developments towards the reporting of more non-financial information, including movements towards Integrated Reporting, suggest that other theories, such as stakeholder theory and stewardship theory, may be worthy of further consideration. Different corporate governance regimes globally may also make agency theory of less use, as it is reflective of an Anglo-American view of firms (Habib and Jiang 2015). Considering the role of the board as a provider of resources, as well as just a monitor of managers, may mean that resource-dependency theory also yields useful insights (Endrikat et al. 2020).

Reporting on corporate governance is also linked to developments in other types of corporate reporting, in particular non-financial reporting. Both mandated changes (such as the recent EU Directive on non-financial reporting) and voluntary disclosures required for other purposes, such as CSR or sustainability, may yield useful insights into corporate governance and may also develop corporate governance reporting. It may also be interesting to study whether or not major global events such as the Covid-19 pandemic lead to changes in corporate governance disclosures as many companies face periods of substantial economic disruption, and therefore increased stakeholder scrutiny.

\section{References}

Alrazi, B., De Villiers, C., \& Van Staden, C. J. (2015). A comprehensive literature review on, and the construction of a framework for, environmental legitimacy, accountability and proactivity. Journal of Cleaner Production, 102, 44-57.

Armstrong, C., Ittner, C., \& Larcker, D. (2012). Corporate governance, compensation consultants, and CEO pay levels. Review of Accounting Studies, 17(2), 322-351.

Bae, K., Baek, J., Kang, J., \& Liu, W. (2012). Do controlling shareholders' expropriation incentives imply a link between corporate governance and firm value? Theory and evidence. Journal of Financial Economics, 105(2), 412-435.

Bear, S., Rahman, N., \& Post, C. (2010). The impact of board diversity and gender composition on corporate social responsibility and firm reputation. Journal of Business Ethics, 97(2), 207-221.

Beattie, V. (2014). Accounting narratives and the narrative turn in accounting research: Issues, theory, methodology, methods and a research framework. The British Accounting Review, 46(2), 111-134.

Bebchuk, L., Cohen, A., \& Ferrell, A. (2009). What matters in corporate governance? The Review of Financial Studies, 22(2), 783-827.

Bhagal, S., Bolton, B., \& Romano, R. (2008). The promise and peril of corporate governance indices. Columbia Law Review, 108(8), 1803-1882. 
Boddy, C. R. (2013). Corporate psychopaths: Uncaring citizens, irresponsible leaders. The Journal of Corporate Citizenship, 49, 8-16.

Bushee, B. J. (1998). The influence of institutional investors on myopic R\&D investment behavior. The Accounting Review, 73(3), 305-333.

Cahan, S. F., De Villiers, C., Jeter, D. C., Naiker, V., \& Van Staden, C. J. (2016). Are CSR disclosures value relevant? Cross-country evidence. European Accounting Review, 25(3), 579-611.

Calder, A. (2008). Corporate governance: A practical guide to the legal frameworks and international codes of practice. Philadelphia: Kogan Page.

Camilleri, M. A. (2015). Environmental, social and governance disclosures in Europe. Sustainability Accounting, Management and Policy Journal, 6(2), 224-242.

Carrott, G. T. (2013). The real work and worth of board committees. Directors \& Boards, 38(1), 26.

Chan, M., Watson, J., \& Woodliff, D. (2014). Corporate governance quality and CSR disclosures. Journal of Business Ethics, 125(1), 59-73.

Cheung, D. T. Y. (2018). A discussion on whether there is justification in incorporating a stakeholder theory into UK corporate governance for private companies in unregulated transactions. The Company Lawyer, 39(10), 315-325.

Chou, H., Chung, H., \& Yin, X. (2013). Attendance of board meetings and company performance: Evidence from Taiwan. Journal of Banking \& Finance, 37(11), 4157-4171.

Christensen, D. M. (2016). Corporate accountability reporting and high-profile misconduct. Accounting Review, 91(2), 377-399.

Cooray, T., \& Senaratne, S. (2020). Does corporate governance affect the quality of integrated reporting? Sustainability, 12(10), 4262.

Croson, R., \& Gneezy, U. (2009). Gender differences in preferences. Journal of Economic Literature, 47(2), 448-474.

Dalton, D. R., \& Dalton, C. M. (2011). Integration of micro and macro studies in governance research: CEO duality, board composition, and financial performance. Journal of Management, 37(2), 404-411.

De Villiers, C. (1998). The Willingness of South Africans to Support more Green Reporting. South African Journal of Economic and Management Sciences, 1(1), 145-167.

De Villiers, C., Naiker, V., \& van Staden, C. J. (2011). The effect of board characteristics on firm environmental performance. Journal of Management, 37(6), 1636-1663.

De Villiers, C., \& van Staden, C. J. (2011). Where firms choose to disclose voluntary environmental information. Journal of Accounting and Public Policy, 30(6), 504-525.

Dumay, J., La Torre, M., \& Farneti, F. (2019). Developing trust through stewardship. Journal of Intellectual Capital, 20(1), 11-39.

Duong, H. K., Kang, H., \& Salter, S. B. (2016). National culture and corporate governance. Journal of International Accounting Research, 15(3), 67-96.

Eberhardt-Toth, E. (2017). Who should be on a board corporate social responsibility committee? Journal of Cleaner Production, 140, 1926-1935.

Eccles, R., \& Krzus, M. (2010). Integrated reporting for a sustainable strategy. Financial Executive, 26(2), 28-32.

Eccles, R., \& Youmans, T. (2016). Materiality in corporate governance: The statement of significant audiences and materiality. Journal of Applied Corporate Finance, 28(2), 39-46.

Endrikat, J., De Villiers, C., Guenther, T., \& Guenther, E. (2020). Board characteristics and corporate social responsibility: A meta-analytic investigation. Business \& Society, forthcoming.

Fasan, M., \& Mio, C. (2017). Fostering stakeholder engagement: The role of materiality disclosure in integrated reporting. Business Strategy and the Environment, 26(3), 288-305.

Ferry, L., \& Ahrens, T. (2017). Using management control to understand public sector corporate governance changes. Journal of Accounting \& Organizational Change, 13(4), 548-567.

Filatotchev, I. (2007). Corporate governance and the firm's dynamics: Contingencies and complementarities. Journal of Management Studies, 44(6), 1041-1056.

Forker, J. J. (1992). Corporate governance and disclosure quality. Accounting and Business Research, 22(86), 111-124.

Fracassi, C., \& Tate, G. (2012). External networking and internal firm governance. Journal of Finance, 67(1), 153-194.

Greco, G. (2011). Determinants of board and audit committee meeting frequency. Managerial Auditing Journal, 26(3), 208-229. 
Grosser, K. (2016). Corporate social responsibility and multi-stakeholder governance: Pluralism, feminist perspectives and women's NGOs. Journal of Business Ethics, 137(1), 65-81.

Grove, H., Patelli, L., Victoravich, L. M., \& Xu, P. (2011). Corporate governance and performance in the wake of the financial crisis: Evidence from US commercial banks. Corporate Governance: An International Review, 19(5), 418-436.

Guiso, L., Sapienza, P., \& Zingales, L. (2015). The value of corporate culture. Journal of Financial Economics, 117(1), 60-76.

Habib, A., \& Jiang, H. (2015). Corporate governance and financial reporting quality in china: A survey of recent evidence. Journal of International Accounting Auditing \& Taxation, 24, $29-45$.

Hambrick, D., Werder, A., \& Zajac, E. (2008). New directions in corporate governance research. Organization Science, 19(3), 381-385.

Hillman, A. J., \& Dalziel, T. (2003). Boards of directors and firm performance: Integrating agency and resource dependence perspectives. Academy of Management Review, 28(3), 383-396.

Hoitash, U., Hoitash, R., \& Bedard, J. (2009). Corporate governance and internal control over financial reporting: A comparison of regulatory regimes. The Accounting Review, 84(3), 839-867.

IODSA. (2016). King IV report on Corporate Governance for South Africa. Retrieved from https:// cdn.ymaws.com/www.iodsa.co.za/resource/collection/684B68A7-B768-465C-8214-E3A00 7F15A5A/IoDSA_King_IV_Report_-_WebVersion.pdf

Jensen, M. C. (1986). Agency costs of free cash flow, corporate finance, and takeovers. The American Economic Review, 76(2), 323-329.

Jensen, M. C. (2010). Value maximization, stakeholder theory, and the corporate objective function. Journal of Applied Corporate Finance, 22(1), 32-42.

Jensen, M. C., \& Meckling, W. H. (1976). Theory of the firm: Managerial behavior, agency costs and ownership structure. Journal of Financial Economics, 3(4), 305-360.

Jizi, M., Salama, A., Dixon, R., \& Stratling, R. (2014). Corporate governance and corporate social responsibility disclosure: Evidence from the US banking sector. Journal of Business Ethics, 125(4), 601-615.

Kaczmarek, S., Kimino, S., \& Pye, A. (2012). Antecedents of board composition: The role of nomination committees. Corporate Governance: An International Review, 20(5), 474-489.

Kolk, A., \& Pinkse, J. (2010). The integration of corporate governance in corporate social responsibility disclosures. Corporate Social Responsibility and Environmental Management, 17(1), 15-26.

La Porta, R., Lopez-de-Silanes, F., Shleifer, A., \& Vishny, R. (2000). Investor protection and corporate governance. Journal of Financial Economics, 58(1-2), 3-27.

Lai, A., Leoni, G., \& Stacchezzini, R. (2019). Accounting and governance in diverse settings-an introduction. Accounting History, 24(3), 325-337.

Lightle, S., Baker, B., \& Castellano, J. (2009). The role of boards of directors in shaping organizational culture. The CPA Journal, 79(11), 68-72.

Llopis, J., Reyes Gonzalez, M., \& Gasco, J. L. (2007). Corporate governance and organisational culture: The role of ethics officers. International Journal of Disclosure and Governance, 4(2), 96-105.

Long, T. (2006). This year's model: Influences on board and director evaluation*. Corporate Governance: An International Review, 14(6), 547-557.

Lysandrou, P., \& Parker, D. (2012). Commercial corporate governance ratings: An alternative view of their use and impact. International Review of Applied Economics, 26(4), 445-463.

Mcnulty, T., Zattoni, A., \& Douglas, T. (2013). Developing corporate governance research through qualitative methods: A review of previous studies. Corporate Governance: An International Review, 21(2), 183-198.

Melloni, G., Stacchezzini, R., \& Lai, A. (2016). The tone of business model disclosure: An impression management analysis of the integrated reports. Journal of Management and Governance, 20(2), 295-320.

Okhmatovskiy, I., \& David, R. (2012). Setting your own standards: Internal corporate governance codes as a response to institutional pressure. Organization Science, 23(1), 155-176.

Parker, L. D. (2017). Corporate Governance. In R. Roslender (Ed.), The Routledge companion to critical accounting (pp. 283-300). London: Routledge.

Pittroff, E. (2016). Whistle-blowing regulation in different corporate governance systems: An analysis of the regulation approaches from the view of path dependence theory. Journal of Management and Governance, 20(4), 703-727. 
Satta, G., Parola, F., Profumo, G., \& Penco, L. (2014). Corporate governance mechanisms and disclosure in medium-sized listed firms: Substitutes or complements? International Journal of Globalisation and Small Business, 6(1), 37-63.

Schiehll, E., \& Martins, H. C. (2016). Cross-national governance research: A systematic review and assessment (advancing the corporate governance research agenda). Corporate Governance: An International Review, 24(3), 181-199.

Segui-Mas, E., Bollas-Araya, H., \& Polo-Garrido, F. (2018). Assurance on corporate governance reports in Spain: Towards an enhanced accountability or a new form of public relations? Administrative Sciences, 8(3), 32.

Shehata, N., Salhin, A., \& El-Helaly, M. (2017). Board diversity and firm performance: Evidence from the U.K. SMEs. Applied Economics, 49(48), 4817-4832.

Shipilov, A. V., Greve, H. R., \& Rowley, T. J. (2019). Is all publicity good publicity? The impact of direct and indirect media pressure on the adoption of governance practices. Strategic Management Journal, 40(9), 1368-1393.

Short, J. C., Broberg, J. C., Cogliser, C. C., \& Brigham, K. H. (2010). Construct validation using computer-aided text analysis (CATA): An illustration using entrepreneurial orientation. Organizational Research Methods, 13(2), 320-347.

Simnett, R., \& Huggins, A. L. (2015). Integrated reporting and assurance: Where can research add value? Sustainability Accounting, Management and Policy Journal, 6(1), 29-53.

Soleimani, A., Schneper, W., \& Newburry, W. (2014). The impact of stakeholder power on corporate reputation: A cross-country corporate governance perspective. Organization Science, 25(4), 991-1008.

Stovall, O., Neill, J., \& Perkins, D. (2004). Corporate governance, internal decision making, and the invisible hand. Journal of Business Ethics, 51(2), 221-227.

Stubbs, W., \& Higgins, C. (2014). Integrated reporting and internal mechanisms of change. Accounting, Auditing \& Accountability Journal, 27(7), 1068-1089.

Suchman, M. C. (1995). Managing legitimacy: Strategic and institutional approaches. The Academy of Management Review, 20(3), 571-610.

Tang, P. C., Fu, S., \& Yang, S. (2019). Do peer firms affect corporate social performance? Journal of Cleaner Production, 239, 118080.

Tao, N. B., \& Hutchinson, M. (2013). Corporate governance and risk management: The role of risk management and compensation committees. Journal of Contemporary Accounting \& Economics, 9(1), 83-99.

Tricker, R. I. (2015). Corporate governance: Principles, policies, and practices (3rd ed.). Oxford: Oxford University Press.

Upadhyay, A. D., Bhargava, R., \& Faircloth, S. D. (2014). Board structure and role of monitoring committees. Journal of Business Research, 67(7), 1486-1492.

Utz, S. (2019). Corporate scandals and the reliability of ESG assessments: Evidence from an international sample. Review of Managerial Science, 13(2), 483-511.

Uysal, N., \& Tsetsura, K. (2015). Corporate governance on stakeholder issues: Shareholder activism as a guiding force. Journal of Public Affairs, 15(2), 210-219.

Velte, P., \& Gerwanski, J. (2020). Current integrated reporting knowledge and future research opportunities - the impact of governance on integrated reporting - A literature review. In C. De Villiers, P. K. Hsiao, \& W. Maroun (Eds.), The Routledge Handbook of Integrated Reporting. London: Routledge.

Wang, X. (2010). Increased disclosure requirements and corporate governance decisions: Evidence from chief financial officers in the pre- and Post-Sarbanes-Oxley periods. Journal of Accounting Research, 48(4), 885-920.

Wang, H., Tong, L., Takeuchi, R., \& George, G. (2016). Corporate social responsibility: An overview and new research directions. Academy of Management Journal, 59(2), 534-544.

Xia, B. S., \& De Beelde, I. (2018). Corporate governance and management incentives: Evidence from the Scandinavian countries. Corporate Governance: The International Journal of Business in Society, 18(1), 1-13.

Publisher's Note Springer Nature remains neutral with regard to jurisdictional claims in published maps and institutional affiliations. 
Charl de Villiers is Professor of Accounting at The University of Auckland, New Zealand, where his research and teaching interests include Management Accounting, Sustainability Accounting, and Integrated Reporting. He is also a professor and adjunct professor at the University of Pretoria, University of Cape Town, and University of the Western Cape, in South Africa. Charl has more than 300 research based publications and presentations, including over 80 articles in refereed journals. He serves on the editorial boards of 10 academic journals, including Accounting, Auditing \& Accountability Journal; British Accounting Review; and Journal of Accounting and Public Policy. He is the editor in chief of Meditari Accountancy Research and an editor of Accounting \& Finance.

Ruth Dimes is a Professional Teaching Fellow and $\mathrm{PhD}$ candidate at the University of Auckland. Ruth teaches financial statement analysis on the Masters of Professional Accounting programme and also teaches accounting subjects on executive education programmes at the University of Auckland. Ruth's research interests are Integrated Reporting, CSR and corporate governance, and she is particularly interested in addressing the gap between academics and practitioners in this field. Prior to entering academia, Ruth worked in financial management roles for major FMCG firms in the UK, and subsequently specialised in executive education consultancy, working both in the UK and Australia. She is a Chartered Accountant and a Fellow of the ICAEW. 